Отримано: 18 серпня 2018 р.

Прорецензовано: 23 серпня 2018 р.

Прийнято до друку: 29 серпня 2018 p.

e-mail: mariya.knir@gmail.com

DOI: $10.25264 / 2311-5149-2018-10(38)-10-14$
Кнір М. О. Державно-приватне партнерство: світовий досвід і досвід України. Наукові записки Начіонального університету «Острозька академія». Серія «Економіка» : науковий журнал. Острог : Вид-во НаУОА, вересень 2018. № 10(38). С. 10-14.

\author{
Кнір Марія Олександрівна, \\ кандидат економічних наук, дочент кафедри фінансів економічного факультету \\ Київського Національного університету ім. Тараса Шевченка
}

\title{
ДЕРЖАВНО-ПРИВАТНЕ ПАРТНЕРСТВО: СВІТОВИЙ ДОСВІД І ДОСВІД УКРАЇНИ
}

Стаття присвячена актуальним проблемам розвитку держсавно-приватного партнерства (ДПП) як необхідного інструменту реалізації сочіальних проектів. Розглянуто сутність категорії ДПП, розкрито особливості його найбільш поширених форм, зокрема в економічі України, враховано економічні і політичні складові, у рамках яких складається проиес формування і розвитку ДПП в світі і в Украӥні.

Ключові слова: Державно-приватне партнерство, концесія, держава, підприємство, проект.

\section{Книр Мария Александровна,}

кандидат экономических наук, доиент кафедры финансов экономического факультета Киевского начионального университета им. Тараса Шевченко

\section{ГОСУДАРСТВЕННО-ЧАСТНОЕ ПАРТНЕРСТВО: МИРОВОЙ ОПЫТ И ОПЫТ УКРАИНЫ}

Статья посвящена актуальным проблемам развития государственно-частного партнерства (ГЧП) как необходимого инструмента реализации сочиальных проектов. Рассматривается сущность категории ГЧП, раскрываются особенности его наиболее распространенных форм, в том числе в экономике Украины, учтены экономические и политические составляющче, в рамках которых складывается прочесс формирования и развития ГЧП в мире и Украине.

Ключевые слова: государственно-частное партнерство, концессия, государство, предприятие, проект.

\section{Mariya Knir,}

PhD, Associate Professor at the Department of Finance, Faculty of Economics

Taras Shevchenko National University of Kyiv, Ukraine

\section{PUBLIC-PRIVATE PARTNERSHIP: WORLD EXPERIENCE AND EXPERIENCE OF UKRAINE}

The article is devoted to problems of development of public-private partnership (PPP) as a necessary tool for the implementation of social projects. Ukraine's economy modernization and priority sectors' and industries' development is impossible without the state-business partnership. Scientific research of the public-private partnership development process, rise of institution and mechanisms facilitating its practical implementation are of high value for the state and private business. Thus within the article, the essence of the PPP category is considered, the features of its most common forms are disclosed. Economic and political framework components for the PPPS formation and development in Ukrainian realities are analyzed. Ukraine has a large potential for the development of many forms of PPPs, however for its practical application it is necessary to take into account a number of fundamental issues such as: the real interests of all parties in the partnership, the stability of the political regime, the predictability of the strategy for further development of the country, the social orientation of the business. In countries with a developed market economy, sufficient PPP experience has been accumulated, which, considering some domestic specifics, can be applied in Ukraine. The analysis of the parties'interests, the mechanism of PPP implementation, as well as the ways for its effective application were examined within the article. The results of examination proved that properly functioning PPP mechanism provides wider benefits from capital investment in public research and creates favorable conditions for sustainable balanced development.

Key words: Public-private partnership, concession, state, enterprise, project.

Постановка проблеми. Еволюція ролі держави в економіці свідчить про те, що характер і методи їі участі в економічних процесах постійно змінюються. Реалізація численних соціально-економічних проектів пов'язана $з$ постійно зростаючими обмеженнями в бюджетній та фінансовій сферах, а також 3 наростаючими вимогами населення до якості суспільних послуг та інфраструктури. У цих умовах стає актуальним пошук нових форм та інструментів впливу на економіку, альтернативах прямого регулювання. Однією $з$ нових форм, яка довела свою ефективність в світі, є державно-приватне партнерство (ДПП) - система партнерських відносин між державою і приватним сектором. 
Аналіз останніх досліджень і публікацій. Проблеми впровадження ДПП в українські реалії почали грунтовно досліджувати в Україні тільки протягом останніх років. Поки що не сформовано цілісної системи теоретико-методологічних підходів ДПП і відносин держави і бізнесу в межах цього формату співпраці. Окремі аспекти цієї проблематики розглянуто у працях вітчизняних учених, серед яких: В. М. Геєць, І. О. Лютий, П. І. Надолішній, І. О. Луніна, І. В. Запатріна, А. І. Куліков та інші. На сьогодні залишаються нерозв'язаними багато важливих питань, зокрема зміст і форми, інтереси сторін, механізм реалізації, а також способи ефективного застосування ДПП в українському державному управлінні й економічній політиці.

Таким чином, наукові дослідження процесу формування інституту державно-приватного партнерства (ДПП) і механізмів його практичної реалізації представляють високу цінність для держави і приватного бізнесу. Актуальним і важливим $є$ також вивчення сучасних підходів до ДПП як в Україні, так і за кордоном.

Метою статті є узагальнення економічних і політичних складових, у межах яких відбувається процес формування і розвитку ДПП у світі і в Україні.

Завданнями статті є висвітлення сутності і форм ДПП, визначення актуальних проблем розвитку ДПП, розкриття особливостей застосування проектів ДПП в економіці України і у світі.

Виклад основного матеріалу. Суmність і переваги ДПП. Державно-приватне партнерство (ДПП) сьогодні - одна 3 найбільш популярних у світі форм співпраці між державою та бізнесом. Це економічна категорія, що $є$ механізмом реалізації громадськими структурами і приватними партнерами довгострокових інвестиційних проектів із метою досягнення завдань соціально-економічного розвитку публічноправових утворень, підвищення рівня доступності та якості публічних послуг, що досягається за допомогою поділу ризиків і залучення приватних ресурсів.

Основними відмінними ознаками державно-приватного партнерства можна вважати такі:

- взаємодія сторін є офіційним, на правовій основі, шляхом укладення договору (контракту, угоди);

- сторонами є держава і приватний бізнес; взаємодія сторін має рівноправний характер щодо умов і поділу результатів;

- суспільно корисну спрямованість співпраці.

У міжнародній практиці співпраця представників держави та бізнесу через державно-приватне партнерство набула значного поширення в більшості соціально значущих сфер, ключовими серед яких є:

- соціальна інфраструктура (реставрація і будівництво медичних, освітніх і культурних установ, їх повне технологічне й організаційне забезпечення, а також підтримання їх життєдіяльності);

- транспортна інфраструктура (будівництво автомобільних і залізних доріг, морських і річкових портів, аеропортів і трубопроводів, а також надання послуг із обслуговування та забезпечення ефективності їхньої діяльності);

- житлово-комунальне господарство (реставрація старих і будівництво нових об'єктів газо-, водо- і електрозабезпечення та водоочисних споруд і їх обслуговування, а також забезпечення належної чистоти і порядку на закріпленій території).

Проекти ДПП мають ряд переваг порівняно з проектами, що реалізуються державним і приватним партнером одноосібно, а саме:

1. Збільшення фінансового й іншого ресурсного забезпечення інфраструктурних проектів, що дозволяє реалізовувати більш масштабні інноваційні й ефективні проекти в істотно скорочені терміни. ДПП відкриває уряду доступ до альтернативних приватних джерел капіталу, дозволяючи реалізувати важливі і термінові проекти, які в іншому випадку навряд чи були б можливі.

2. Інтенсифікація реалізації інфраструктурних та інших проектів. Залучення до реалізації проектів державою зацікавлених приватних партнерів із їх фінансовими, організаторськими, інтелектуальними ресурсами, які доповнюють можливості держави, мультиплікує результуючий ефект, дозволяючи істотно інтенсифікувати реалізацію інфраструктурних та інших проектів, істотно скоротити терміни забезпечення споживача тими чи іншими інфраструктурними можливостями.

3. Ефективний спосіб скоротити публічні видатки на реалізацію проекту і забезпечити найбільш ефективне й оптимальне співвідношення ціни і якості в публічному секторі. Механізми ДПП мають істотний потенціал створення і реалізації інфраструктурних проектів, які дозволяють більш ефективно застосовувати державними ресурси і можливості, частково вивільнити державні ресурси і можливості для інших проектів і пропонують умови для державних установ, що дозволяють досягти кращого співвідношення ціни і якості завдяки поліпшенню розподілу ризиків, інновацій, поліпшенню використання активів і методів управління.

4. Оптимальний розподіл ризиків. Оптимальність розподілу ризиків означає, що певні ризики, які більш економічно ефективно управляються суб'єктами державного сектора, беруться в управління державного партнера, а інші - більш ефективно керовані суб'єктами приватного сектора, беруться останніми у своє управління. 
5. Забезпечення управлінської інноваційності. Цілий ряд видів діяльності суб’єктів державного сектора може бути реалізований з істотно більшою ефективністю під час використання управлінських технологій приватного сектора. Злиття мотивації і навичок державного і приватного секторів, а також укладання контрактів на конкурсній основі розширюють можливості для використання новаторських підходів до здійснення державних інфраструктурних проектів на основі ДПП.

6. Зняття з держави істотної частки організаційного та часового навантаження. Передача відповідальності за надання деяких державних послуг створює можливість органам державної влади зосередити свою увагу на здійсненні планування і контролю. Це дозволяє виключити з числа функцій державних органів ряд надлишкових питань, а значить підвищити ефективність державного управління.

7. Підвищення якості послуг, їх інфраструктурних та інших можливостей. Зарубіжний досвід реалізації проектів ДПП свідчить про те, що якість послуг у межах ДПП вище, ніж під час реалізації усталеної моделі державних закупівель. Такий результат може бути досягнутий за допомогою інтегрованості виробників послуг, за допомогою економії внаслідок масштабності проекту, а також за допомогою впровадження інновацій.

Світовий досвід реалізації ДПП. Із метою узагальнення досвіду реалізації ДПП у різних країнах світу можна виділити три узагальнені стадії розвитку ДПП, які об’єднують відповідні характеристики цих стадій і групи країн.

До першої стадії розвитку (вищої), де державою створені умови і передумови для ефективної реалізації ДПП, слід віднести Великобританію й Австралію. Зазначені країни характеризуються застосуванням різноманітних за розділенням вкладів і ризиків моделей партнерства, що охоплюють усі періоди життєвого циклу проектів, залучення різних категорій інвесторів, враховуючи приватні і пенсійні інвестиційні фонди. Проект ДПП із розвитку лондонського метрополітену, який дозволив залучити десятки мільярдів фунтів у модернізацію лондонського метро і приніс прибуток інвесторам-учасникам проекту, має світову славу.

Приклад Великобританії в контексті ДПП дуже показовий. Саме ця країна є одним зі світових лідерів у реалізації проектів ДПП. На сьогодні тільки у сфері охорони здоров'я тут реалізовують понад 130 проектів ДПП, включаючи проект будівництва лікарні St. Bartholomew вартістю 1,1 млрд фунтів стерлінгів.

На середній стадії знаходиться більшість розвинутих країн, зокрема США, Японія, Франція, Канада i Німеччина. Застосування інституту ДПП у зазначених країнах наближене за різноманітністю застосовуваних моделей до першої групи, проте за масштабом охоплення галузей і територіальних рівнів спостерігається деяке відставання. Водночас рівень розвитку моделей ДПП можна охарактеризувати як високий. У компаніях цих країн, що реалізують інфраструктурні проекти, утворені спеціальні підрозділи, використовують широкий спектр інструментів для їх фінансування.

Країни третьої групи, що знаходяться на початковій стадії розвитку, в числі яких знаходиться і Україна, тільки приступають до формування законодавчої бази й інституційного середовища ДПП, питання ДПП тільки недавно стали обговорювати на різних рівнях державного апарату і бізнес-спільноти, кількість реалізованих проектів невелика і форми застосовуваних моделей не відрізняються різноманітністю. Метою цього етапу є всебічне вивчення досвіду інших країн і власних напрацювань, а також формування громадської думки і штату фахівців зі структурування проектів за моделями ДПП. У цій групі країн на початковій стадії знаходяться також Китай, Індія, Словаччина, Латвія, Чехія, Польща, Угорщина, Бельгія, Фінляндія, Мексика, Бразилія, Росія.

Використання механізмів ДПП дозволяє країнам підвищити свою конкурентоспроможність, яка є спільною інтегральної оцінкою розвиненості країни загалом. Країни з високим рівнем конкурентоспроможності характеризуються наявністю розвиненого інституційного середовища, що генерує доходи, високоякісної інфраструктури, стабільністю макроекономічного середовища, високою якістю систем охорони здоров'я та вищої освіти. Відкритість ринку і розвинений фінансовий сектор створюють основу для швидкого впровадження інновацій, що сприяють підвищенню якості життя населення.

Особливості реалізації ДПП в Украӥні. Для України ДПП - один із найперспективніших способів залучення інвестицій у державну і комунальну інфраструктуру. На сьогодні завдяки інформаційній кампанії, розгорнутій владою разом із вітчизняними ЗМІ довкола актуальності ДПП, у суспільства є узагальнене уявлення про сутність та переваги ДПП і механізм його дії коли державні об'єкти, серед яких: дороги, аеропорти, морські порти, підприємства водо- й енергопостачання тощо, передаються на певних умовах приватному партнеру. Спектр застосування ДПП і концесійних механізмів у вітчизняній практиці $\epsilon$ значно багатшим і різноманітнішим, що збагачує наш досвід і викриває потенційн можливі ризики.

1. Львівські замки і палаци. Ідея передачі замків у концесію народилася у 2007 році, коли оновлювався Перелік об'єктів права державної власності, які можуть надаватися в концесію. Переліком було визначено три Львівських замки як потенційні об'єкти концесії. Однак на практиці всі спроби були невдалими - фінансування проектів так і не було розпочато. 
2. Міський благоустрій. Прикладом поширеного формату вітчизняного ДПП є Коломийський договір, предметом якого стало будівництво спортивного комплексу та проведення благоустрою міського озера. Вигода приватного партнера полягала в отриманні земельної ділянки в місті та права здійснювати будівництво житлових будинків на ній.

3. Багатоквартирні будинки. Сьогодні будівництво багатоквартирних будинків уже не приховується за гаслами розвитку міської соціальної інфраструктури, а прямо декларують як мету проекту для участі в конкурсі. Водночас відсоток від загальної площі приміщень у будинку, який переможець конкурсу (приватне підприємство) має за умовами конкурсу передавати замовнику (державі), коливається в межах $5-20 \%$.

4. Переобладнання котелень. Популярність енергосервісних контрактів зумовлена, насамперед, наявністю бюджетних гарантій. Тим не менше такі проекти є позитивним прикладом ініціативності громад, хоча і є лише тимчасовим заходом.

5. Переробка сміття. Ідея реалізації проекту будівництва комплексу з переробки твердих побутових відходів у Полтавській області полягала в будівництві декількох заводів, які обслуговували б область. Задля цього підписувалися окремі договори з усіма сільськими радами, всього було підписано 109 договорів [6]. Ця ідея зазнала краху, тому зі всіх укладених концесіоних договорів на практиці виявилося нуль реалізованих проектів. Ці випадки не $є$ поодинокими та свідчать про те, що вітчизняна статистична звітність і практична результативність проектів ДПП стоять далеко один від іншого.

Скептики ДПП найчастіше апелюють до браку повноцінного, спеціального законодавства щодо ДПП. Справді, прийнятий у 2010 році Закон України «Про державно-приватне партнерство» так повноцінно i не запрацював. Однак навіть чинне цивільне та господарське законодавство дозволяс реалізовувати проекти у форматі класичного ДПП. Доказ цьому - ряд проектів, провал яких не пов'язаний із браком спеціального законодавства.

В Україні було досить спроб реалізувати проекти ДПП. Більшість проектів стосувалося розвитку інфраструктурних об'єктів і видобутку корисних копалин, що характерно для подібного роду співпраці між державою та бізнесом в Україні. Розглянемо найцікавіші проекти як із погляду моделі реалізації, так і 3 точки зору етапів підготовки.

1. Проект спільного розвитку міжнародного аеропорту «Сімферополь». Стартувавши влітку 2011 року, проект планували реалізовувати спільно з Шанхайською будівельною групою (приватний партнер, Китай), компанією «Інвесткеп» (координуючий партнер, Великобританія) і Радою міністрів Автономної Республіки Крим (державний партнер, Україна). Загальна вартість проекту становила близько \$300 млн. Модель реалізації ДПП передбачала створення спеціальної проектної компанії (SPV). Для цілей фінансування проекту, крім коштів приватного партнера, планували залучити позиковий капітал від Китайського банку розвитку (CDB) й Експортно-імпортного банку Китаю (China Eximbank). Проект ДПП «Міжнародний аеропорт» Сімферополь пройшов усі етапи узгодження в межах Ради міністрів АР Крим і був представлений на розгляд кредитних комітетів CDB i China Eximbank. Засідання комітетів планували на весну 2014 року, проте події лютого-березня 2014 року не дозволили довести проект до логічного завершення.

2. Проект концесії причалів Свпаторійського морського торгового порту на о. Донузлав, що стартував у грудні 2010 року. Приватним партнером була китайська компанія CNTIC (China National Technical Import \& Export Corporation), координуючим партнером - Агентство регіонального розвитку АР Крим, а державним партнером планувало стати Міністерство інфраструктури України. Проект передбачав будівництво повноцінного торгового порту на о. Донузлав з орієнтовною вартістю понад 1 мільярд доларів США. Проект зупинили на етапі підготовки техніко-економічного обгрунтування з причини політичного форс-мажору.

3. У контексті історії підготовки ДПП в Україні варто згадати провальні угоди про розподіл продукції (УРП) в межах пошуку, розвідки та видобутку вуглеводнів на Юзівському й Олеському родовищах. Приватними партнерами за цими угодами у 2013 році були компанії Shell (Юзівське родовище) i Chevron (Олеське родовище). Пізніше Shell i Chevron відмовилися від участі в проектах ДПП. Причини відмови поточні події на сході України і скандали навколо координуючого партнера щодо обох проектів.

Висновки. Отже, розвиток державно-приватного партнерства дозволяє створити синергію можливостей органів державного управління й органів місцевого самоврядування, а також ефективності приватного капіталу, дозволяє залучити значні інвестиції в економіку. Механізм ДПП при правильному функціонуванні забезпечує отримання більш широких переваг від капіталовкладень, створюючи сприятливі передумови для стійкого збалансованого розвитку.

В Україні є масштабний потенціал для розвитку багатьох форм державно-приватного партнерства, однак для його практичного застосування необхідне рішення ряду принципових питань. По-перше, слід ураховувати реальні інтереси всіх учасників договору. У нашій країні сильна так звана політична традиція, коли держава відіграє виняткову роль та іноді втручається в автономні сфери життя суспільства, зокрема і в компетенцію бізнесу, не завжди обгрунтовуючи свої дії законодавчо. Не сприяють упрова- 
дженню ДПП в Україні і негативні політичні події. Все це перешкоджає встановленню довірчих і конструктивних відносин із підприємцями.

Український приватний бізнес залишається багато в чому незрілим учасником взаємодії з владою. Соціальна орієнтованість бізнесу ще недостатньо розвинена. Великий, середній, а також малий бізнес демонструють прагнення здебільшого до отримання прибутку, перерозподілу коштів бюджету, а не до інвестування чи іншої участі в глобальних проектах, що мають особливе значення для економіки країни. Ефективне партнерство можливе тільки за умови повної ясності та передбачуваності стратегії подальшого розвитку країни. У країнах із розвиненою ринковою економікою накопичено достатній досвід ДПП, який з урахуванням вітчизняної специфіки може бути застосований в Україні.

\section{Лiтература:}

1. Special Issue: Government and Business Regulation: (2016) Controlling the Implementation of the Publicprivate Partnership (PPP) Projects. Edited By: Mihail N. Dudin. Journal of Internet Banking and Commerce. Vol. 21, S 4.

2. Tahir M. Nisar (2007) Risk Management in Public-Private Partnership Contracts. Public Organization Rev. 7:1-19 DOI 10.1007/s11115-006-0020-1.

3. World Bank Group (2018) Public-Private Partnerships. URL: https://www.worldbank.org/en/topic/ publicprivatepartnerships/overview.

4. Закон України «Про державно-приватне партнерство» / Верховна Рада України. URL: http://zakon.rada. gov.ua/laws/show/2404-17.

5. Закон України «Про концесії» / Верховна Рада України URL: http://zakon.rada.gov.ua/laws/show/997-14

6. Запатріна I. В. Публично-частное партнерство для целей устойчивого развития: моногр. Київ, 2017. $312 \mathrm{c}$.

7. Грищенко С. Підготовка та реалізація проектів публічно-приватного партнерства: Практичний посібник для органів місцевої влади та бізнесу. Київ, 2011. - 140 c. URL: http://enefcities.org.ua/upload/files/PPP_report_ USAID_2011_ua.pdf. 